\title{
Engaging students with clickers in language lessons
}

\author{
Janet, Man-wai Cheung ${ }^{1 *}$, Alan, Nga-lun Wong ${ }^{1}$, Emmy, Yin-ha Chan ${ }^{2}$ \\ From Practical Social and Industrial Research (PSIR) Symposium 2014 \\ Wanchai, Hong Kong. 5 December 2014
}

\section{Background}

To engage students, researchers have been integrating clickers in classroom delivery for study. Clickers, also known as 'personal response systems' [1], 'student response systems (SRS), audience response systems (ARS), or personal response systems (PRS)',[2] are a technology that allow students to respond to the teacher in real time and receive instant feedback from the teacher, thus enhancing learning and teaching[3]. Featuring instance and interaction, the technology can cater to students' needs and learning styles as '[Net Generations] are used to interactive, participatory, investigative enquiry'[3]. Some researchers have explored the functions and effectiveness of clickers for use as question aids in class [4], promotion of active learning[1,2] and improvement in learning[5]. This study aimed to investigate the effect of clickers as a pedagogical approach on student satisfaction.

\section{Methods}

A web app with the clicker function was integrated into the teaching of English and Communication at Foundation Diploma Level in IVE (LWL), wherever found suitable, as a pedagogical method to engage learners for one semester in one of the classes in which three English modules were delivered. The three modules included one listening and speaking module and two reading and writing modules. The two classes involved in this research were taught by the same teacher. The same sets of TLP were used in the 2 classes, but the difference was in the delivery of selected activities during class: adoption of clickers versus nontechnology-aided activities. The teacher would explain answers based on the instant results from the clickers. The corresponding exercises would be replaced by other activities such as discussion in the other class. With model

\footnotetext{
* Correspondence: janet@vtc.edu.hk

${ }^{1}$ Centre for Learning and Teaching, Vocational Training Council, Hong Kong Full list of author information is available at the end of the article
}

answers, the questions were set in the form of multiple choice or short questions. At the end of the semester, the two classes were invited to do a perception survey and interview.

\section{Results}

Students reflected that using clickers motivated them to learn in lessons (mean: 3.64), supported their learning (mean: 3.72 ) and reflected the learning progress to the teacher (mean: 3.74), and these values were higher than those in the class using non-technology-aided activities (reported means of 3.33, 3.71 and 3.71, respectively). Seventy-two per cent of the students indicated their interest in future lessons with clicker technology.

As challenges, $26 \%$ reflected that they were distracted by the mobile technology, which is $5 \%$ higher than that in the other class. Failed and incomplete clicker attempts were recorded in all of the clicker activities due to a weak Wi-Fi connection. The average rate of incompletion of clicker activities was around $43 \%$.

\section{Conclusions}

In general, the positivity in students' feedback showed the favorability of clickers as a learning tool. In future, clicker questioning techniques, effective ways of embedding clickers in teaching, and their relation with active learning and learning effectiveness can be areas for further study.

\footnotetext{
Authors' details

${ }^{1}$ Centre for Learning and Teaching, Vocational Training Council, Hong Kong. ${ }^{2}$ Language Centre, Hong Kong Institute of Vocational Education (Lee Wai Lee), Hong Kong.

Published: 4 December 2014
1. Sternberger CS: Interactive learning environment: Engaging students using clickers. Nurs Educ Perspect 2012, 33(2):121-124.

References
} Attribution License (http://creativecommons.org/licenses/by/4.0), which permits unrestricted use, distribution, and reproduction in any medium, provided the original work is properly credited. 
2. Martyn M: Clickers in the classroom: An active learning approach. Educausereview Online [Internet]., c-2007 [cited 2013 Dec 2]. Available from: http://www.educause.edu/ero/article/clickers-classroom-activelearning-approach.

3. Murphy B, Smark CJ: N-Gens of change: Personal response systems and Net-Generation students. University of Wollongong Research Online [Internet]., c-2006 [cited 2014 Feb 19]. Available from: http://ro.uow.edu.au/ cgi/viewcontent.cgi?article=3211\&context=commpapers.

4. Laxman K: A study on the adoption of clickers in higher education Australasian J Educ Technol 2011, 27(8):1201-1303.

5. Yourstone SA, Kraye HS, Albaum G: Classroom questioning with immediate electronic response: Do clickers improve learning? Decision Sciences Journal of Innovative Education 2008, 6(1):75-88.

doi:10.1186/2193-1801-3-S1-O8

Cite this article as: Cheung et al:: Engaging students with clickers in language lessons. SpringerPlus 2014 3(Suppl 1):O8.

\section{Submit your manuscript to a SpringerOpen ${ }^{0}$ journal and benefit from:}

- Convenient online submission

- Rigorous peer review

- Immediate publication on acceptance

- Open access: articles freely available online

- High visibility within the field

- Retaining the copyright to your article

Submit your next manuscript at $\gg$ springeropen.com 